\title{
In vitro evaluation of six chemical agents on smooth Brucella melitensis strain
}

\author{
Zhen Wang ${ }^{1}$, Peng Fei Bie ${ }^{2}$, Jie Cheng ${ }^{1}$, Qing Min Wu ${ }^{2^{*}}$ and Lin $\mathrm{Lu}^{1^{*}}$
}

\begin{abstract}
Brucellosis is a zoonosis that disseminated by a variety of ways between animals and humans. The effective disinfection of contaminated environments, soil, feces, and animal bodies plays an irreplaceable role in the prevention and control of brucellosis. To kill Brucella effectively, the bactericidal effects of frequently used disinfectants (including aldehydes, halogens, quaternary ammonium compound, phenolics, and alkalines) and the potential factors that influence disinfection effects were determined in the present study. The results revealed that the minimum bactericidal concentrations (MBCs) of the six disinfectants were all significantly lower than the routinely used concentrations, and all the tested disinfectants were effective against B. melitensis NI. The results of quantitative determination showed that the bactericidal effects of the disinfectants were influenced by their concentration, exposure time, dirty condition and the temperature. Under dirty conditions and a low temperatures, sodium hypochlorite and sodium hydroxide showed better bactericidal effect, while benzalkonium chloride was almost without bactericidal ability. In addition, increasing the disinfectant concentration at low temperatures can improve the bactericidal effect. The present study suggested that Brucella is sensitive to commonly used disinfectants. However, the bactericidal effect is vulnerable to dirty conditions and low temperatures. Thus, it is necessary to test the in vitro sensitivity of disinfectants that are commonly used on farms or the new disinfectant formulations periodically, with the aim of improving the efficacy of animal and human brucellosis prevention programs.
\end{abstract}

Keywords: Brucella, Bactericidal effect, Disinfectants, Zoonosis

\section{Introduction}

Brucella spp. is a Gram-negative bacterium that is spread widely through a variety of means [1]. In domestic and wild animals, Brucella infection predominantly causes abortions during late gestation in females and orchitis and epididymitis in males [2]. Brucellae are primarily discharged into the environment via milk, vaginal discharges after abortion, and/or by urine, feces, or through the slaughtering of infected animals. Brucella can stay and remain active in a contaminated environment for many months, depending on conditions such as suitable temperature, $\mathrm{pH}$, and humidity, [3]. Some reports have shown that Brucella could survive in dust, manure, water, manure slurry, aborted fetuses, soil, meat and dairy products for considerable periods of time [4]. Human and animal infections originate from

\footnotetext{
*Correspondence: wuqm@cau.edu.cn; lulin1209@163.com

${ }^{2}$ Key Laboratory of Animal Epidemiology and Zoonosis of the Ministry of Agriculture, College of Veterinary Medicine, China Agricultural University, Beijing 100193, China

${ }^{1}$ Animal Science and Technology College, Beijing University of Agriculture, Beijing 102206, China
}

\section{Biomed Central}

direct or indirect contact with infected animals or Brucellacontaminated environments.

Brucella is known to be susceptible to heat treatment, disinfection, and direct sunlight [5]. Disinfection with chemical reagents is no doubt an important element in animal brucellosis control and eradication campaigns [6]. There are various classes of chemical disinfectants, including acids and their esters, alcohols, aldehydes, biguanides, halogens, heavy metals, oxidizing compounds, phenols and phenolic compounds, quaternary ammonium compound, quinoline and isoquinoline derivatives and dyes [7]. The selection of a disinfectant should be based on the function of disinfectant is expected to perform. All disinfectant types have advantages and disadvantages, and each has its own scope of application. For example, glutaraldehyde is a high level disinfectant for heat sensitive equipment, and which is noncorrosive to metal, and active in presence of organic material, but it is extremely irritating and toxic to skin and mucous membranes. Chlorine is a intermediate level disinfectant that used for disinfect 
biological material, equipment, medical supplies, and environmental surface. It is low cost, fast acting, but corrosive to metals and irritant to skin and mucous membranes [8]. The ideal disinfectant for clinical practice must fit several criteria, including water solubility, germicidal ability and cost-effectiveness according to their disinfectant targets, environments and environmental temperatures [9].

Many reports have indicated that Brucella species are readily killed by most of the commonly available disinfectants including hypochlorite solutions, 70\% ethanol, isopropanol, iodophores, phenolic disinfectants, formaldehyde, glutaraldehyde and xylene $[5,10]$. However, little has been reported on the effects of the application conditions, especially with regards to low temperatures, the appropriate dosages of the disinfectants, and the organic matter that is present in dirty conditions. In the present study, Brucella melitensis which is the predominant strain associated with the epidemic of brucellosis in China, and six types frequently-used disinfectants in china were selected, and were evaluated in vitro for their biocidal activity on Brucella melitensis according different parameters: different disinfectant concentrations, contact time, temperature and in presence of different interfering conditions.

\section{Materials and methods}

\section{Bacterial preparation}

This study was performed with $B$. melitensis NI. This bacterium is an epidemic strain that was isolated from an aborted bovine fetus in China. This strain is referred to as smooth virulent $B$. melitensis strain biovar 3 , and it induces abortion in pregnant cattle, sheep, and goats [11]. Three days prior to the study, a pure culture of $B$. melitensis NI was plated onto tryptone soya agar (TSA, $\mathrm{BD})$ and incubated at $37^{\circ} \mathrm{C}$ with $5 \%$ (vol $\left./ \mathrm{vol}\right) \mathrm{CO}_{2}$ for $72 \mathrm{~h}$ to one week. A bacterial suspension at $\mathrm{OD} 600=1.0$ (equivalent to about $10^{9} \mathrm{cfu} / \mathrm{mL}$ ) was prepared in physiological saline for the tests.

\section{Chemical disinfectants and their corresponding neutralizing agents}

Six disinfectant types, including aldehydes, halogens, quaternary ammonium compound, phenolics, and alkalines, were selected on the basis of their active ingredients (Table 1). All disinfectants were freshly prepared according to the manufacturer's instructions prior to testing. The corresponding neutralizing agents for each disinfectant were also freshly prepared [12]. Sterile distilled water was used as a diluent and as a disinfectant control.

\section{The MBC determination of six chemical disinfectants}

Each disinfectant was diluted from the recommended concentration by a two-fold serial dilution method using sterile distilled water in test tubes. $100 \mu \mathrm{L}$ of bacterial suspension $\left(10^{9} \mathrm{cfu} / \mathrm{mL}\right)$ was added to test tubes containing the different concentrations of each disinfectant, vortexed and incubated for $20 \mathrm{~min}$. The final volume of disinfectant that was added to each bacterial sample was $2 \mathrm{~mL}(100 \mu \mathrm{L}$ of bacterial suspension with $1.9 \mathrm{~mL}$ of the different concentrations for each disinfectant). Sterile distilled water served as a control. After the exposure time, the test tubes were vortexed again and $100 \mu \mathrm{L}$ of the bacterial suspension from all concentrations of each disinfectant was evenly spread over the TSA plates, each sample spread three plates. The growth was assessed after incubating for $72 \mathrm{~h}$ (control group) or one week (disinfection group) at $37^{\circ} \mathrm{C}$ with $5 \% \mathrm{CO}_{2}$, and the minimal inhibitory concentration (MIC) value was determined. The lowest concentration at which the bacteria could not survive was recorded as MIC. Then, $0.5 \mathrm{~mL}$ MIC bacterial suspensions were sub-cultured in $4.5 \mathrm{~mL}$ liquid media without chemicals at $37^{\circ} \mathrm{C}$ with $5 \% \mathrm{CO}_{2}$ to determine bacterial survival. After

Table 1 The disinfectants and neutralizing agents used in this study

\begin{tabular}{|c|c|c|c|c|c|c|}
\hline \multicolumn{5}{|l|}{ Disinfectants } & \multicolumn{2}{|l|}{ Neutralizing agents } \\
\hline Classification & Active ingredients & $\begin{array}{l}\text { Recommended } \\
\text { concentration }\end{array}$ & $\begin{array}{l}\text { Recommended } \\
\text { contact time }\end{array}$ & Optimal application & Active ingredients & $\overline{\text { Concentration }}$ \\
\hline Aldehydes & Glutaraldehyde & $4 \%$ & $20 \mathrm{~min}$ & Equipment, goods & Glycine & $2 \%$ \\
\hline \multirow[t]{2}{*}{ Halogens } & Sodium hypochlorite & $2 \mathrm{~g} / \mathrm{L}$ & $20 \mathrm{~min}$ & $\begin{array}{l}\text { Biological material, } \\
\text { smooth surface }\end{array}$ & Sodium thiosulfate & $0.2 \%$ \\
\hline & $\begin{array}{l}\text { Trichloroisocyanuric } \\
\text { acid }\end{array}$ & $4 \mathrm{~g} / \mathrm{L}$ & $30 \mathrm{~min}$ & $\begin{array}{l}\text { Lab environment, } \\
\text { Medical supplies }\end{array}$ & Sodium thiosulfate & $0.4 \%$ \\
\hline $\begin{array}{l}\text { Quaternary ammonium } \\
\text { compound }\end{array}$ & $\begin{array}{l}\text { Benzalkonium } \\
\text { chloride }\end{array}$ & $0.2 \mathrm{~g} / \mathrm{L}$ & / & $\begin{array}{l}\text { Skin, mucous } \\
\text { membranes }\end{array}$ & $\begin{array}{l}\text { Tween-80+ } \\
\text { Phosphatidylcholine }\end{array}$ & $0.5 \%+1 \%$ \\
\hline Phenolic & Lysol & $10 \mathrm{~g} / \mathrm{L}$ & $30 \mathrm{~min}$ & Object surface & Tween-80 & $1 \%$ \\
\hline Alkaline & Sodium hydroxide & $10 \mathrm{~g} / \mathrm{L}$ & / & Field, animal housing & Hydrochloric acid & $10 \%$ \\
\hline
\end{tabular}

Providers for each disinfectants: Glutaraldehyde (Sinopharm Chemical Reagent Co., Ltd); Sodium hypochlorite (Beijing KeLinLong Ann medical technology co., LTD); Trichloroisocyanuric acid (Beijing ChangJiangMai Medical Technology Industry); Benzalkonium chloride (Beijing HaiDeRun Pharmaceutical CO., LTD); Lysol (Dezhou Ansett high-tech disinfection products co., LTD); Sodium hydroxide (Sinopharm Chemical Reagent Co., Ltd).

"l" indicate there is no recommended contact time. 
$72 \mathrm{~h}, 100 \mu \mathrm{L}$ of the mixed culture were spread over a TSA plate, and the MBCs of the tested disinfectants were determined [13]. Testing was performed in triplicate. The limit of detection in this test is $7 \mathrm{CFU} / \mathrm{mL}$.

\section{The bactericidal effect of chemical disinfectants under different conditions}

To evaluate the influence of interfering conditions during disinfection, the bactericidal effect of each disinfectant was determined by using the MBC values in physiological saline, soil suspensions, and fecal suspensions. In brief, soil and feces were collected from a cattle shelter and made into $20 \%$ soil or $20 \%$ fecal suspensions. Samples of the soil and fecal suspensions were autoclaved at $115^{\circ} \mathrm{C}$ for $20 \mathrm{~min}$ and cooled at room temperature. The Brucella bacteria were then added to achieve a final bacterial concentration of $10^{9} \mathrm{cfu} / \mathrm{mL}$. Afterward, $100 \mu \mathrm{L}$ of bacteria suspension in physiological saline, soil and fecal suspensions were added to test tubes containing $1.9 \mathrm{~mL}$ of each disinfectant at the MBC concentration. Sterile distilled water served as a negative control. The exposure periods were $1 \mathrm{~min}, 5 \mathrm{~min}$, and $10 \mathrm{~min}$. After each exposure time, $2 \mathrm{~mL}$ of the corresponding neutralizing agents were added to the test tubes and neutralized for $10 \mathrm{~min}$. These mixtures were 10-fold diluted and plated onto TSA to monitor the viable bacteria counts. Each sample spread three plates. The bactericidal activities of each disinfectant were expressed as logarithmic reductions in viable organisms and were calculated as follows: reduction factor $(\mathrm{RF})=$ Log10 cfu (negative control)-Log10 cfu (disinfection group) [14].

\section{The bactericidal effect of chemical disinfectants at low temperatures}

To evaluate the influence of low temperatures on the bactericidal effects, each disinfectant, bacteria suspensions in physiological saline, and soil or fecal suspensions were prepared as described above and kept on ice for $1 \mathrm{~h}$. Next, $100 \mu \mathrm{L}$ of the bacterial sample was added to test tubes containing $1.9 \mathrm{~mL}$ of each disinfectant at the $\mathrm{MBC}$ or at 2-fold the MBC. The reactions were incubated on ice for 1, 5, and $10 \mathrm{~min}$ [15]. After the appropriate contact time, $2 \mathrm{~mL}$ of the corresponding neutralizing agents were added to the test tubes and neutralized for $10 \mathrm{~min}$ and viable bacteria counts were monitored. The bactericidal activities of each disinfectant at different concentrations and low temperatures were calculated by employing the reduction factor [14].

\section{Statistical analysis}

Quantitative data for the bacterial counts were expressed as the means and SD values of the Log10 reduction value $(\mathrm{n}=3)$. Statistical analysis was performed by ANOVA. Significant differences were accepted at $P<0.05$.

\section{Results}

The MIC and MBC for chemical disinfectants

The MIC and MBC determination results of each disinfectant are summarized in Table 2. As expected, all six disinfectants exhibited high efficacy against B. melitensis NI. For the aldehyde disinfectants, the MIC of glutaraldehyde was $0.125 \%$; for halogens, $125 \mathrm{mg} / \mathrm{L}$ sodium hypochlorite and $125 \mathrm{mg} / \mathrm{L}$ trichloroisocyanuric acid were effective against B. melitensis NI. The MIC values for benzalkonium chloride, lysol, and sodium hydroxide were $0.002 \%$, $0.156 \%$, and $0.312 \%$, respectively. In addition, the $\mathrm{MBC}$ determination showed that $B$. melitensis NI failed to survive after being sub-cultured in media without the tested disinfectants, a blank space suggesting that the MICs and MBCs were equivalent (Table 2).

\section{Bactericidal effects under different interfering conditions}

The bactericidal effect of six chemical disinfectants under different conditions was determined. As shown in Figure 1, we observed that the reduction factors (RF) of glutaraldehyde, trichloroisocyanuric acid, benzalkonium chloride, and lysol in the feces suspension were significantly lower than that in physiological saline $(P<0.05)$. In the soil suspension, the RFs of these disinfectants increased with respect to that of the feces, but benzalkonium chloride still had the lowest RFs at $1.33 \pm 0.23$, $1.60 \pm 0.08$, and $2.46 \pm 0.20$ within 1,5 , and $10 \mathrm{~min}$, respectively. Among the six disinfectants, sodium hypochlorite and sodium hydroxide were the most effective under all three conditions, with RFs of $8.47 \pm 0.11$ and $8.56 \pm 0.21$ for $10 \mathrm{~min}$, respectively. In addition, the reaction time can also influence the bactericidal effects. For example, the RFs of glutaraldehyde in physiological saline were $2.61 \pm 0.07,4.89 \pm 0.02$, and $8.90 \pm 0.14$ after 1 , 5 , and $10 \mathrm{~min}$, respectively.

\section{Bactericidal effects at low temperatures}

To evaluate the influence of low temperatures on the bactericidal effects of chemical disinfectants, Brucella bacteria samples and the tested disinfectants were cooled on ice before the test, and the reactions were also incubated on ice. As shown in Figure 2, the RFs were clearly reduced for all the disinfectants in both physiological saline and dirty conditions $(P<0.05)$. This finding was especially true for benzalkonium chloride, which almost lost its bactericidal ability with RFs of $0.08 \pm 0.20,0.22 \pm 0.08$, and $0.46 \pm$ 0.18 after 1,5 , and $10 \mathrm{~min}$, respectively, in the soil suspension. Moreover, the reaction time seemed to be more important under low temperatures and dirty conditions. Given a reaction time of $1 \mathrm{~min}$, the RFs of sodium hypochlorite, trichloroisocyanuric acid, benzalkonium chloride, and sodium hydroxide in soil and those of glutaraldehyde, trichloroisocyanuric acid, and benzalkonium chloride in feces were all less than 1, and along with the extension in 
Table 2 The MBC of each disinfectant that was determined in this study

\begin{tabular}{|c|c|c|c|c|}
\hline Disinfectant & Contact time & MIC & MBC & Recommended concentration \\
\hline Glutaraldehyde & $20 \mathrm{~min}$ & $0.125 \%^{a}$ & $0.125 \%{ }^{\mathrm{a}}$ & $4 \%$ \\
\hline Sodium hypochlorite & $20 \mathrm{~min}$ & $125 \mathrm{mg} / \mathrm{L}^{\mathrm{a}}$ & $125 \mathrm{mg} / \mathrm{L}^{\mathrm{a}}$ & $2000 \mathrm{mg} / \mathrm{L}$ \\
\hline Trichloroisocyanuric acid & $20 \mathrm{~min}$ & $125 \mathrm{mg} / \mathrm{L}^{\mathrm{a}}$ & $125 \mathrm{mg} / \mathrm{L}^{\mathrm{a}}$ & $4000 \mathrm{mg} / \mathrm{L}$ \\
\hline Benzalkonium chloride & $20 \mathrm{~min}$ & $0.002 \%^{a}$ & $0.002 \%{ }^{a}$ & $0.02 \%$ \\
\hline Lysol & $20 \mathrm{~min}$ & $0.156 \%^{\mathrm{a}}$ & $0.156 \%^{\mathrm{a}}$ & $10 \%$ \\
\hline Sodium hydroxide & $20 \mathrm{~min}$ & $0.312 \%^{\mathrm{a}}$ & $0.312 \%^{a}$ & $10 \%$ \\
\hline
\end{tabular}

${ }^{a} P<0.05$ (significant) in comparison with the corresponding recommended concentration.

the exposure time, the RFs increased to some degree. To improve the bactericidal effect of disinfectants at low temperatures, 2-fold $M B C$ values were used for each disinfectant. As shown in Figure 3, the RFs of the tested disinfectants at low temperatures increased and even exceeded the value found at room temperature. It is notable that the RFs of glutaraldehyde, sodium hypochlorite, and sodium hydroxide reached 9.00 for $10 \mathrm{~min}$, meaning that $100 \%$ of the bacteria were killed. In addition, when maintained at a low temperature with 2-fold the $\mathrm{MBC}$, sodium hypochlorite and sodium hydroxide were still the most effective.

\section{Discussion}

Brucellosis is a highly contagious zoonosis that affects the public health and economic performance of many countries, especially in developing and underdeveloped nations, due to local husbandry methods and the lack of effective carcass and apoblema disposal, the environment was significantly contaminated with brucellosis. The pathogen, Brucella spp. is usually transmitted between animals through contact with contaminated environment and related products $[16,17]$. In addition, it was reported that Brucellae have been isolated from Nile catfish and rat in Egypt [18], which also indicate high threaten of brucellosis to environments. And most human cases are caused by occupational exposures to infected environments or by the ingestion of unpasteurized dairy products [5]. Disinfectants can interrupt the transmission of microorganisms and provide a public health benefit [19]. Thus, the use of effective disinfectants and appropriate disinfection measures are important process in preventing human infections and for preventing the spread of brucellosis on farms.

As previously described the disinfectant efficacy is known to depend on the concentration, time of exposure, temperature, and reaction conditions [20,21]. However, each disinfectant has its own application objectives, and disinfectant-related studies have not been adequately performed for Brucella. In this study, the bactericidal effects were determined for commonly used chemical disinfectants against Brucella. These findings indicate that the concentrations and the exposure times of these disinfectants at the determined MBC values could inhibit and kill Brucella, and the MBC values were much lower than the corresponding recommended concentrations (Table 2, $P<0.05)$. Although the higher concentrations may be more effective at killing pathogens, much of the compound that remains could also have side effects on the environment.

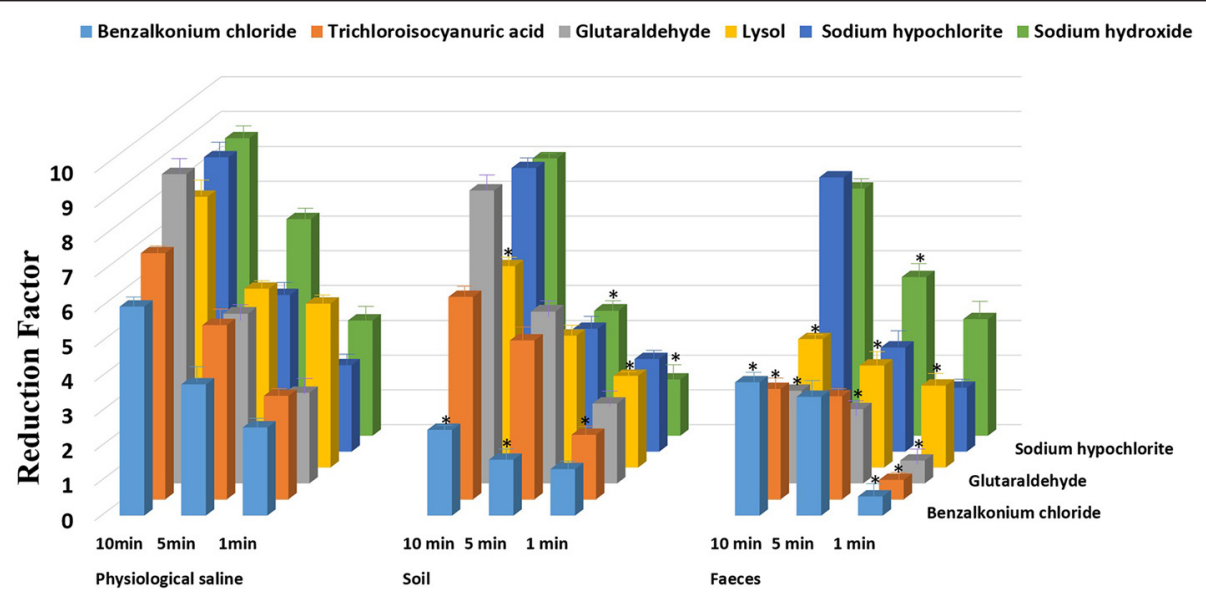

Figure 1 The quantitative bactericidal effects of each disinfectant under different conditions at room temperature. Reduction factors: The mean and SD of the Log10 cfu (negative control)-Log10 cfu (disinfection group). ${ }^{*} P<0.05$ (significant) in comparison with the value for the physiological saline group. 


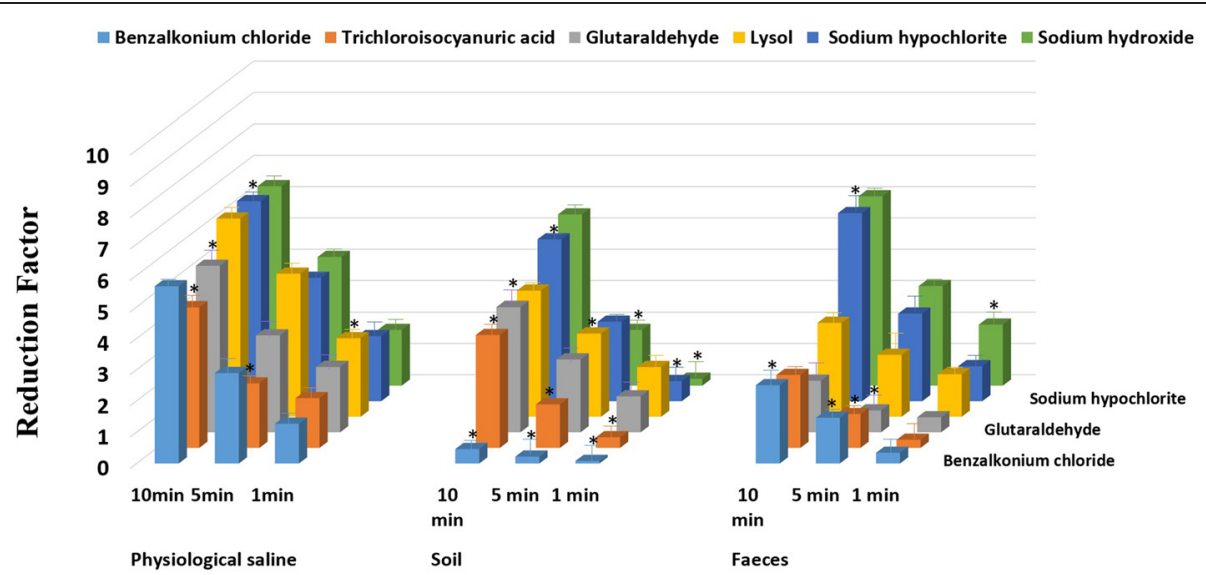

Figure 2 The quantitative bactericidal effects of each disinfectant in different media at a low temperature. Reduction factors: The mean and SD of the Log10 cfu (negative control)-Log10 cfu (disinfection group). ${ }^{*} P<0.05$ (significant) compared with the value at room temperature.

Thus, it is necessary to readjust the usage concentration of disinfectants for the field disinfection process on the basis of environmental temperatures, the degree of organic matter contamination, pathogen concentration, and the disinfectants used, because the volatile and residual disinfectants may influence the environmental quality.

Although the bactericidal activity of disinfectants usually increases along with the contact time under specific conditions, liquid disinfectants can be less effective or inactivated under dirty conditions or at a low temperature [7]. Our results indicated that dirty conditions and low temperatures lowered the bactericidal effects, but higher concentrations of disinfectants and prolonged reaction times could enhance the bactericidal effects of each disinfectant on Brucella. Under low temperatures, the RFs of 2-fold MBCs were higher than the MBCs. These results indicated that low temperatures and concentrations influenced the bactericidal effects of the tested disinfectants to some extent. Moreover, the influence of these conditions was related to the category of disinfectants, for example, sodium hypochlorite and sodium hydroxide were barely influenced by dirty conditions and low temperatures, and the bactericidal effect of benzalkonium chloride was significantly reduced under dirty conditions and low temperatures $(P<0.05)$. Thus, it is necessary to set the guidelines for chemical disinfection use for dirty conditions especially in the fall and winter seasons.

In conclusion, given the results obtained by this study, it may be concluded that all these disinfectant types including aldehydes, halogens, quaternary ammonium compound, phenolics, and alkalines could be selected for disinfection to prevent brucellosis. Sodium hypochlorite and sodium hydroxide are preferred under dirty conditions and low temperatures. Actually, the two disinfectants are often

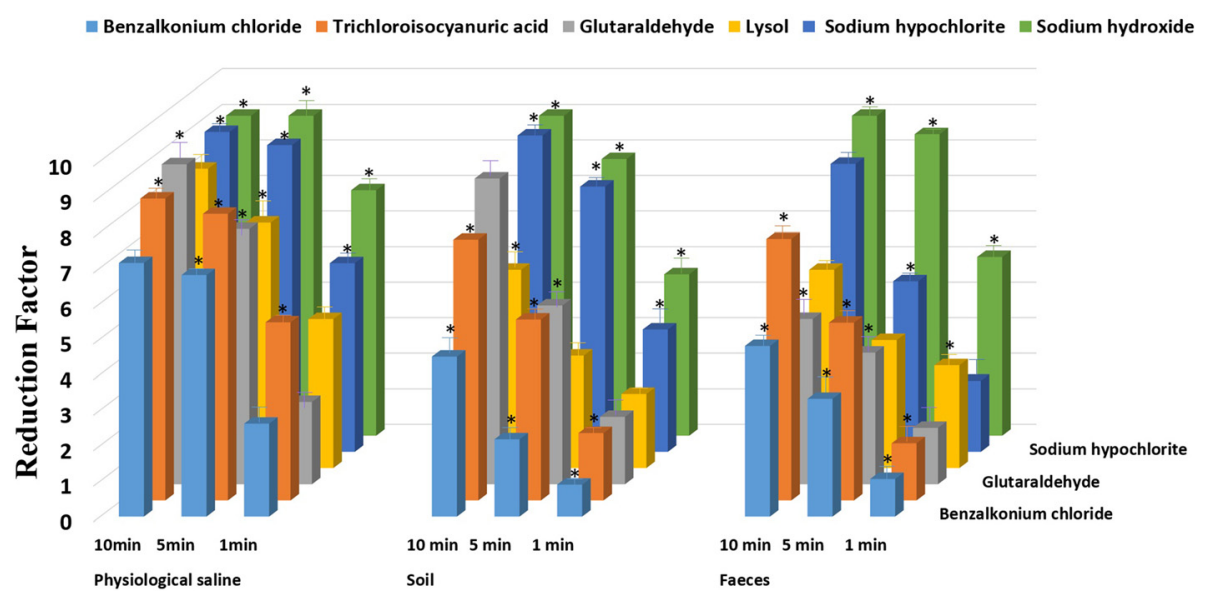

Figure 3 The quantitative bactericidal effects of each disinfectant with 2-fold the MBC at a low temperature. Reduction factors: The mean and SD of the Log10 cfu (negative control)-Log10 cfu (disinfection group). ${ }^{*} P<0.05$ (significant) in comparison with the value at a low temperature with the MBC. 
selected on the basis of their ease of use, lower price and low toxicity [22]. In general, the present results suggested that in the process of brucellosis prevention and control, sodium hydroxide is preferred for animal housing environment and field disinfection, and sodium hypochlorite is preferred for laboratory, biological material, medical supplies, and smooth surface disinfection.

\section{Competing interests}

The authors declare that they have no competing interests.

\section{Authors' contributions}

ZW carried out the MBC determination test, participated in all study design, anddrafted the manuscript and. PFB carried out all the experiments. JC completed all the data analysis. QMW and LL conceived the study and helped draft the manuscript. All authors read and approved the final manuscript.

\section{Acknowledgments}

This work was supported by the Beijing Dairy Industry Innovation Team and the National Basic Research Program of China, Program 973 (2010CB530202).

Received: 23 December 2014 Accepted: 11 March 2015

Published online: 21 March 2015

\section{References}

1. Corbel MJ. Brucellosis: an overview. Emerg Infect Dis. 1997;3:213-21.

2. Enright FM. In: Mielsen K, Duncan Jr, editors. The pathogenesis and pathobiology of Brucella infection in domestic animals brucellosis. Boston: CRC Press Inc; 1990. p. 301-20.

3. The Centers for Food Security and Public Health. Bovine brucellosis: Brucella abortus. Available at: http://www.cfsph.iastate.edu/Factsheets/pdfs/brucellosis_ abortus.pdf. Last Updated: July 2009.

4. WHO Library Cataloguing-in-Publication Data. Brucellosis in humans and animals; 2006.

5. Pappas G, Akritidis N, Bosilkovski M, Tsianos E. Brucellosis. N Engl J Med. 2005;352:2325-36.

6. Office International des Epizooties. Manual of diagnostic tests and vaccines for terrestrial animals. 5th ed. Paris: Office International des Epizooties; 2004.

7. McDonnell G, Russell AD. Antiseptics and disinfectants: activity, action, and resistance. Clin Microbiol Rev. 1999;12(1):147-79.

8. Rutala WA. APIC guideline for selection and use of disinfectants. 1994, 1995, and 1996 APIC Guidelines Committee. Association for Professionals in Infection Control and Epidemiology, Inc. Am J Infect Control. 1996;24 (4):313-42.

9. Kennedy J, Bek J, Griffin D. Selection and use of disinfectants. NebGuide, Ref. G1410, University of Nebraska-Lincoln, USA; 2005.

10. Canada PHA MSDS - Brucella. Available at: http://www.phac-aspc.gc.ca/lab$\mathrm{bio/res/psds-ftss/msds23e-eng.php.}$

11. Liu W, Jing Z, Ou Q, Cui B, He Y, Wu Q. Complete genome sequence of Brucella melitensis biovar 3 strain NI, isolated from an aborted bovine fetus. J Bacteriol. 2012;194(22):6321.

12. Park YJ, Chen J. Mitigating the antimicrobial activities of selected organic acids and commercial sanitizers with various neutralizing agents. J Food Prot. 2011;74(5):820-5.

13. Saejung C, Hatai K, Sanoamuang L. The in-vitro antibacterial effects of organic salts, chemical disinfectants and antibiotics against pathogens of black disease in fairy shrimp of Thailand. J Fish Dis. 2014;37(1):33-41.

14. Suller MT, Russell AD. Antibiotic and biocide resistance in methicillin-resistant Staphylococcus aureus and vancomycin resistant enterococcus. J Hosp Infect. 1999:43:281-91.

15. Jang $Y$, Lee J, So B, Lee $K$, Yun $S$, Lee $M$, et al. Evaluation of changes induced by temperature, contact time, and surface in the efficacies of disinfectants against avian influenza virus. Poult Sci. 2014;93(1):70-6.

16. Tittarelli M, Di Ventura M, De Massis F, Scacchia M, Giovannini A, Nannini D, et al. The persistence of Brucella melitensis in experimentally infected ewes through three reproductive cycles. J Vet Med B Infect Dis Vet Public Health. 2005;52:403-9.
17. Wilesmith JW. The persistence of Brucella abortus in calves: a retrospective study of heavily infected herds. Vet Rec. 1978;103(8):149-53.

18. Wareth G, Hikal A, Refai M, Melzer F, Roesler U, Neubauer H. Animal brucellosis in Egypt. J Infect Dev Countries. 2014;8(11):1365-73.

19. Cozad A, Jones RD. Disinfection and prevention of infectious disease. Am J Infect Control. 2003;31:243-54.

20. Bessems $E$. The effect of practical conditions on the efficacy of disinfectants. Int Biodeter Biodegrad. 1998;41(3-4):177-83.

21. Bragg R, Jansen A, Coetzee M, van der Westhuizen W, Boucher C. Bacterial resistance to quaternary ammonium compounds (QAC) disinfectants. Adv Exp Med Biol. 2014;808:1-13.

22. Alabi OS, Sanusi EA. Efficacy of three disinfectant formulations against multidrug resistant nosocomial agents. Afr J Clin Exp Microbiol. 2012;13(3):178-82.

\section{Submit your next manuscript to BioMed Central and take full advantage of:}

- Convenient online submission

- Thorough peer review

- No space constraints or color figure charges

- Immediate publication on acceptance

- Inclusion in PubMed, CAS, Scopus and Google Scholar

- Research which is freely available for redistribution

Submit your manuscript at www.biomedcentral.com/submit 